\title{
Dementia narratives in contemporary German women's writing
}

\author{
Valerie Heffernan \\ Maynooth University
}

\begin{abstract}
As the population ages and dementia becomes more commonplace, we have seen a corresponding increase in the frequency and popularity of works of fiction about this illness. This article looks at two recent German novels that feature characters with dementia, Katharina Hagena's Der Geschmack von Apfelkernen [The Taste of Apple Seeds] (2008) and Kathrin Gerlof's Alle Zeit ['All the Time'] (2009). I explore how literary texts can encourage readers to engage with the human side of this dementia by allowing them to imagine what it might feel like to care for a loved one with this debilitating illness or to develop dementia themselves. I further examine how this insight can be made even more potent when the writer incorporates particular narrative strategies and stylistic devices that replicate the confusion and disorientation that are central to dementia. Ultimately, I make a case for the particular role that fictional literature can play in promoting empathy for people with dementia and their caregivers.

Keywords: dementia narrative, empathy, German women's writing, Katharina Hagena, Kathrin Gerlof
\end{abstract}

According to the latest figures from the World Health Organization, there are around 47 million people worldwide living with Alzheimer's disease and other forms of dementia (WHO 2017). With the world's population now living longer, this number is set to increase to more than 131 million by 2050 (Alzheimer's Disease International 2016: Foreword), leading health professionals and cultural commentators alike to predict that the disease will become an epidemic of our times (WHO and Alzheimer's Disease International 2012: v). While the medical community continues its quest to understand the disease and to find a cure for it, government ministries and agencies are turning their attention to identifying 
ways of improving the lives of those living with dementia. Lack of understanding about the disease can lead to sufferers and their families being subjected to isolation and discrimination. It is for this reason that a recent joint report by the World Health Organization and Alzheimer's Disease International, which calls on all nations to recognise dementia as a public health priority, also emphasizes the 'urgent need to improve the awareness and understanding of dementia across all levels of society as a step towards improving the quality of life of people with dementia and their caregivers' (2012: 4).

Literary texts certainly have a role to play in promoting awareness of dementia and understanding for its sufferers and their carers. Alongside the increase in prevalence of dementia, there has been a rise in the number and variety of novels, dramas, films, and television programmes that depict characters who are living with dementia or caring for loved ones with the illness. Indeed, critics Aagje Swinnen and Mark Schweda describe the proliferation of literary and cultural representations of dementia in recent years as a cultural “dementia boom"' (2015: 10). Swinnen and Schweda argue that contemporary depictions of dementia not only contribute to the cultural mainstreaming of the disease but also shape the cultural construction of the disease in the public arena. It is therefore important to question whether contemporary literary and cultural engagements with the disease reinforce existing, predominantly negative stereotypes that further stigmatize people with dementia and their caregivers, or whether they encourage understanding and empathy with sufferers and their loved ones.

This article considers the representation of dementia in two recent novels by contemporary German women writers and questions the extent to which they foster empathy towards people with dementia and their caregivers. It seems fitting to focus particular attention on German literature given Germany's particularly high rate of dementia relative to other European countries. There are currently almost 1.6 million Germans living with a diagnosis of dementia, and this figure is set to rise to 3 million by 2050 (Deutsche Alzheimer Gesellschaft 2016: 1). The relatively high incidence of dementia there is not entirely surprising when one considers that Germany also has one of the oldest populations of all European countries; with $20.8 \%$ of its population over the age of sixty-five, Germany is second only to Italy (Eurostat 2015).

The social and economic implications of population ageing have provoked considerable debate in the public arena, and this anxiety has also made its way into literary texts. Indeed, Stuart Taberner identifies old age as a 'major theme' (2013: 10) in contemporary German-language literature, and he points 
to a plethora of recent novels, short stories, dramas, and poems that deal with ageing and related issues such as senescence, elder care, loss of sexual function, impending death, and dementia. A recent issue of Oxford German Studies, edited by Marie Isabel Matthews-Schlinzig, is devoted to end-of-life narratives and 'writing in extremis' (2015: 1). Recent articles by Ulrike Vedder (2012) and Irmela Marei Krüger-Fürhoff (2015) focus more specifically on the representation of Alzheimer's and dementia in contemporary literature. Vedder (2012) uses texts by Ulrike Draesner, Katharina Hacker, Annette Pehnt, Arno Geiger, and Brigitte Kronauer, among others, to demonstrate the potential of literature to reflect on societal anxieties about ageing and dementia. Krüger-Fürhoff discusses the difficulty of portraying the loss of memory, language, and identity that go hand-in-hand with dementia 'in ways that do not merely register this loss, but render it palpable to readers' (2015: 91), and she discusses how authors such as Arno Geiger deal with this complex issue.

This article contributes to the growing body of literature on the portrayal of ageing and dementia in contemporary German literature by focusing on how these issues are represented by two contemporary women writers. It is particularly appropriate to look at how this disease is addressed in novels by and about women, given that dementia is seen as an illness that often has a much greater impact on women than on men. A 2015 study found that women were almost twice as likely as men to develop Alzheimer's disease in the course of their lifetime (Alzheimer's Association 2017: 25). Women are also far more likely to take on the role of caregiver to an elderly relative suffering from dementia (Alzheimer's Association 2017: 33). It is for these reasons that Maria Shriver, author of the Shriver Report on Women and Alzheimer's, calls Alzheimer's 'a woman's disease' and one which, moreover, is 'dramatically changing the way we live as families' (ABC News 2010).

The two novels under scrutiny in this essay, Katharina Hagena's Der Geschmack von Apfelkernen (2008), published in English as The Taste of Apple Seeds (2013), and Kathrin Gerlof's Alle Zeit ('All the Time', 2009, not yet translated into English), depict the family history of several generations of women. Both novels look at the ways in which family stories are passed from one generation to the next and explore how past events impact on the present as well as on the relationships between the women. Significantly, both novels feature female characters who are living with dementia, and thus have the potential to offer the reader insight into the devastating effects of dementia on the sufferer and her family. This article investigates the particular ways in which each novel depicts the challenge of dementia and questions the extent to which 
they promote empathy and understanding for the person living with dementia and her loved ones.

In focusing on literature's potential to foster empathy, I draw on Suzanne Keen's theory of narrative empathy, as expounded in her book Empathy and the Novel (2007). Keen probes the presumption that reading fiction makes readers more compassionate to others' needs and by extension inspires altruistic action aimed at improving the situation of those unknown others. Though Keen finds little empirical evidence to support the belief that reading fiction inspires prosocial action, her examination of scholarship on emotional responses to literature on one hand and her own research among readers on the other suggest that reading novels may indeed foster empathy with fictional characters. Keen seeks to develop a working theory of narrative empathy through identifying those features and styles of literary fiction that are particularly successful in cultivating empathy in readers. My article employs Keen's ideas to explore how Hagena and Gerlof use literary technique in a way that both offers the reader insight into the complexities of dementia and promotes compassion for the person with dementia and her caregivers.

\section{The carer perspective: Katharina Hagena's The Taste of Apple Seeds}

Katharina Hagena's The Taste of Apple Seeds tells the story of three generations of women of the Lünschen family: Bertha, the woman with dementia whose death serves as a starting point for the novel; Bertha's daughters Christa, Inga, and Harriet, who must find some way to cope with their mother's illness; and Christa's daughter Iris, the first-person narrator of the novel and sole heir to the family home in the small town of Bootshaven in the far north of Germany. This house, with its garden and apple orchard, is the heart and soul of this family; Bertha was born and raised in this house, and she in turn brought up her own family here. The house is also the site where all of the traumatic events of this family have taken place; it is here that Bertha's sister Anna contracted the pneumonia that ultimately led to her death at the age of sixteen and here that Harriet's daughter Rosmarie met her unfortunate death, also at the age of sixteen, after a fall through the glass roof of the garden house.

To date, the scholarship on this novel has focused on its reflection of contemporary trends in German literature to read family history as reflective of the broader traumatic history of the twentieth century. Monika Shafi places the family home at the centre of her analysis and investigates 'how individual biography and family ancestry are mediated through a house' (2012: 53) in 
Hagena's narrative. I have argued elsewhere that the strong focus on relationships between mothers and daughters and on intergenerational storytelling in this novel align it to contemporary literary attempts to reconstruct an alternative, matrilineal history (Heffernan 2015). Though neither of these studies focuses specifically on Bertha's dementia, both relate the interplay of remembering and forgetting that is brought to the surface by Bertha's illness to the need for preservation of the family memories as a way of understanding the complex family history (Shafi 2012: 65; Heffernan 2015: 41).

Bertha's close association with the family home causes Iris, the narrator, to remark: 'Over the decades she had so fused with the house that, had they performed an autopsy on her, I'm sure by looking at the twists and turns in her brain or the network of her veins they would have been able to produce a route map of the house' (Hagena 2013: 29). Given this intimate interconnection between Bertha, the family home, and family memories, it is perhaps also fitting that the memory loss that is the first sign of her dementia begins at home, with her forgetting the names of household objects or how to perform everyday domestic chores. Bertha's confusion and disorientation only become obvious when she begins to get lost in the village and can no longer find her way back to the house she has lived in all of her life. One by one, she forgets the names of her daughters, and she even leaves notes for herself to remind her of her own name. When she can no longer remember how to get from the kitchen to the dining room, Christa, Inga, and Harriet come to the difficult decision to put Bertha into a home. However, Bertha's removal from the house in Bootshaven ultimately severs her link to her memories and her past. Iris even remarks on the irony in the word 'home' to describe the institution where Bertha spends the last fourteen years of her life; this 'home' can never replace her family home (170).

Hagena's novel also employs various domestic metaphors to represent the Bertha's dementia. Of particular note in this regard is that this type of complexity plays a part in fostering empathy among readers. Keen (2015: 90) points to research by Jèmeljan Hakemulder which indicates that readers are more likely to react with compassion to characters who are different from them when fictional texts are complex enough to require an imaginative investment on their part. The use of literary devices such as metaphor can thus play a part in encouraging readers to bridge the imaginative gap between themselves and the fictional character.

In the early stages of her illness, when she is still lucid enough to describe what is happening to her, Bertha herself compares her mind to the egg timer that sits in her kitchen; the fine sand that trickles constantly through it is like 
the relentless attrition of her memories. Iris, her granddaughter, likens the progression of Bertha's illness to her gradual loss of control of another familiar domestic task, namely her knitting. Iris is fascinated by the woollen oddments that her grandmother produces from her knitting needles:

The looser the mesh of Bertha's mind, the larger the chunks of memory that slipped through. As she became more confused, the woollen things that she knitted became ever crazier: because she was constantly dropping stitches, knitting different patterns together, or starting new stitches at the seams, they grew and shrank in all directions, gaped and felted, and could be unpicked at any point. (10-11)

It is evident that Iris's mother Christa also relates these woollen scraps to her mother's illness and to the sadness she feels about it. Christa gathers up these chaotic woollen oddments but clearly cannot bring herself to throw them away, and Iris is surprised to stumble upon a box of the scraps in her mother's wardrobe. Christa's explanation for saving the woollen fragments - 'I suppose that each of us has to preserve our tears somewhere' (11) - echoes an idea from their family lore that the redcurrant bushes in the garden turned white after the untimely death of Iris's great-aunt Anna, so that the jam made from them resembled 'preserved tears' (2). In calling on this familial belief, Christa offers both a vindication of Bertha's confusion and a reflection of her own deep sadness at the toll that her mother's illness has taken on her own life.

The Taste of Apple Seeds is especially powerful in capturing the impact of Bertha's dementia on the entire family and in particular how Christa, Inga, and Harriet struggle to deal with the physical and emotional burden of caring for their mother. In this aspect, Hagena's novel reflects what Martina Zimmermann (2010) has identified as a common trope in fictional literature about dementia, namely that it often depicts the perspective of the grown-up child of the dementia sufferer rather than that of the person with dementia. She argues that literary texts narrated from this point of view can aid readers to understand the complex emotional and ethical challenges faced by carers as they struggle to deal with the decline of the person they love. Hagena's text depicts the distress that Bertha's illness causes her daughters as well as the pressure it places on them.

For example, the novel emphasizes the impact of this responsibility on the sisters' relationship with each other. A particular source of tension between the three sisters is the fact that Christa lives in southern Germany, with her husband 
and daughter, and thus cannot contribute as much to the work of caring for Bertha as Inga or Harriet, who live much closer to Bertha's care home:

When Christa was there in the school holidays and looked after Bertha, it was hard for Inga and Harriet to be civil to her and fair-minded. When Christa was sad and shocked by the deterioration of Bertha's memory, her younger sisters found it hard to feel compassion. They felt contempt instead. Their sister had no idea how bad, strenuous and frightening it really was. (172)

This conflict between the three sisters comes to a head after Bertha's death. Christa is deeply hurt that Inga and Harriet waited until the evening after their mother's passing to call her to share the news. It is not till Bertha's funeral that the three sisters are reunited. Standing at her mother's graveside, Christa takes from her handbag the various woollen oddments she has collected over the years, 'the holes in Bertha's memory turned into wool' (173), and throws them on top of her coffin, one by one, as if in recognition of the loss that they represent, both to Bertha and to her loved ones. Finally understanding that Christa too has suffered, Inga and Harriet take her hands and the three sisters are reconciled at their mother's graveside, united in their grief.

What does the reader learn about dementia from Hagena's The Taste of Apple Seeds? The narrative tells a personal story of the illness as a trauma that affects all of the family members in ways that might be unexpected. Hagena's novel makes this impact clear by focusing on the emotional and psychological burden faced by Bertha's daughters, as they struggle to deal with their mother's illness. Iris's description of their anger, fear, and sadness underlines the toll her dementia takes on each of them individually, as they struggle to accept the gradual loss of the mother who has played such a central role in their lives, as well as on the relationship between them. Indeed, the fact that these events are relayed through the youngest member of the family, two generations removed from the dementia sufferer, serves to underline the broader impact of the illness on all family members. Hagena's particular focus on the burden of care borne by the female family members presents dementia as a disease that has a profound impact on family life as well as on relationships within the family. 


\section{The perspective of the person with dementia: Kathrin Gerlof's Alle Zeit}

Similar to The Taste of Apple Seeds, Kathrin Gerlof's novel Alle Zeit tells the family story of five generations of women. It begins with a chance meeting on a park bench between eighty-year-old Klara, an elderly woman suffering from dementia who lives in a care home near the park, and seventeen-year-old Juli, who is heavily pregnant and alone, having lost her mother and grandmother in a tragic accident. Through its shifting narrative perspective, the novel allows us to view the events through the eyes of these two protagonists, as well as from those of their female family members; and in the mélange of interconnected stories, it soon becomes clear to the reader that Klara is actually Juli's great-grandmother, who lost contact with the family after an argument with her daughter, Juli's grandmother. The novel also tells the story of Juli's mother Elisa and grandmother Henriette, who take a trip back to the family home in a small town in eastern Germany - a trip which finally enables them to talk about the painful memories of the past but also leads to their untimely deaths. Finally, through the inclusion of the fifth daughter in this female family line, Juli's newborn daughter Svenja, the novel explores how the mistakes and misunderstandings that feed into the complex family narrative can be carried down through the generations.

To date, Gerlof's novel has merited relatively little attention from scholarship, despite the fact that it reflects a trend in contemporary German-language literature of family novels that look back on the National Socialist past from the perspective of the present. A book chapter by Astrid Köhler (2013) is an exception to this rule; Köhler argues for reading Alle Zeit as a more compact form of the great contemporary family novels that uses family history as a means of exploring German history of the twentieth century. Though she makes mention of Klara's dementia as a hindrance to her attempts to reconstruct her personal history, this is not a focal point of her analysis. This article seeks to add to the existing scholarship by both highlighting the significance of this novel and placing its depiction of dementia at the forefront of analysis.

Gerlof's Alle Zeit uses a multiperspectival narrative technique, where the different chapters of the narrative are written from the different perspectives of the various female family members. This technique is critical to its depiction of dementia, since it means that the reader also gets to experience the world from Klara's point of view, a circumstance which allows him/her insight into the perspective of a person who is living with dementia. At the point where we first encounter Klara in the novel, her dementia has not yet affected her daily life to the point where she needs constant care; in the opening scene on the park bench, 
she remarks to Juli that her memory, particularly of recent events, is not what it used to be. She asks Juli for help with remembering the word for 'the things that you put on your head', and when Juli suggests the word 'hat', it does not sound familiar to her (Gerlof, 2009: 5-6). ${ }^{1}$ On the other hand, the gaps in Klara's memory can also include quite significant details; for example, on one occasion, she objects to one of the carers in the home addressing her as 'Granny Simon'; 'Never became a granny. And don't want to be called that' (9). However, she subsequently remembers that she had a daughter, Henriette, and that Henriette had a daughter called Elisa, and that both were killed in an accident; she is aware of the importance of this piece of information and keeps it to herself like a secret treasure. Klara's lapses in memory come and go. At times, she has difficulty remembering her own name, where she is and how she came to be there, and at others, she is quite lucid and surprises even herself with the clarity of her thoughts. Throughout the narrative, Klara seems remarkably aware of the progression of her illness and its effect on her memory and intellect. Although she jokes with Juli about her receding memory - 'I can read the newspaper three times. It's always news to me. That saves you money' (6) - she also feels immense sadness, anger, and anxiety about what is happening to her.

The novel's use of narrated monologue is particularly helpful in offering the reader insight into Klara's thought processes; indeed, Keen (2007) makes particular note of the potential of this literary technique to promote empathy in readers. Narrated monologue, also known as 'free indirect speech' or 'free indirect discourse', is a technique by which a character's speech and thoughts are related in the third person as though from an internal perspective. This technique is particularly successful in enabling a reader to identify with a character, since the reader has the impression of having unmediated access to that character's thoughts, emotions, hopes, and fears. Since, as Keen argues, 'character identification often invites empathy, even when the character and reader differ from each other in all sorts of practical and obvious ways' (2007: xii), Gerlof's use of narrated monologue is very effective in fostering empathy in the reader.

The efficacy of narrated monologue is apparent in the following passage, in which Klara's plan to take a walk is hindered by the sudden appearance in her mind of her long-dead husband:

Klara has Franz in her head again, and there he is now, making himself comfortable. Taking up space that she needs to make it through the day. At least, that's what she thinks. Suddenly she can't remember the way to the exit or whether it's winter or summer outside. Franz is blocking her 
way. It would be easy to find answers to both questions. She could ask somebody. But if she does that, she certainly won't be allowed to leave the house. (82)

As is evident from this excerpt, the use of narrated monologue means that we are party to the confusion, anxiety, and rambling that characterize Klara's dementia. Her thoughts often appear unconnected, and the past, embodied here by Franz, intrudes on her present, often in unpleasant ways. At the same time, Klara's weighing-up of the consequences of asking for help indicates her awareness of the development of her illness and of how she might be perceived by others as vulnerable or incapable of looking after herself.

Gerlof's characterization of Klara is arguably the novel's forte, and the shifting narrative perspective allows her to be presented as a complex and multidimensional individual. In the excerpts told from Henriette's point of view, Klara is painted as a hard and unforgiving mother, an authoritarian who is only concerned with how her family appears to the outside world. In the chapters told from Klara's own perspective, on the other hand, we see an image of a woman who has had to struggle through very difficult circumstances, a woman who had to bring up her daughter alone while her beloved husband was fighting at the front; a woman who had an affair with a Soviet officer at the end of the war in return for food for her daughter; a woman who has beaten breast cancer and now faces an illness which is eroding her hold on the present. Klara's life has not been easy, but her optimism and her humour despite these difficulties make her a likeable character and one the reader is likely to identify with. This makes the depiction of dementia from her eyes all the more potent.

\section{The legacy of dementia}

The multigenerational structure of Hagena's Der Geschmack von Apfelkernen and Gerlof's Alle Zeit lends itself to exploring issues of (female) family heritage and intergenerational transmission. Both novels consider the question of what is passed from one generation to the next and what is concealed from the following generations. The legacy of previous generations may take the form of possessions or belongings; it may centre on the family memories and stories that are passed down through the family as they are told to the subsequent generations; or it may be a physical legacy, a genetic predisposition to a particular illness that is passed from mother to daughter. These three forms of family legacy are presented in Hagena's and Gerlof's novels, and they serve also to link the past 
with the present, mother with daughter. Significantly, the issue of inheritance is closely connected in both novels to that of dementia.

The question of inheritance is one that is central to The Taste of Apples Seeds from the outset. The starting point of the story is the death of Bertha and her decision to leave the family home to her granddaughter, Iris. In effect, Iris is the only family member to inherit anything of any real value. The land that Bertha has left to Christa, her eldest daughter, is worthless; the shares she has left to Inga, her second, are of little value; and she has little or no money left to leave to Harriet, her youngest daughter. It is not clear whether Bertha deliberately bypassed her daughters to leave her house to Iris or whether she was simply unaware of the value of her other possessions. The enormous significance of the house in Bertha's and the family's life makes it a very meaningful legacy, but the house has been the site of so much pain and trauma over the years that Iris is initially unsure whether she is prepared to accept her inheritance. As Shafi argues, Iris spends quite a long time sitting on the threshold - both literally and symbolically - as she comes to terms with the legacy of her grandmother (2012: 55). Her ultimate acceptance of her inheritance and her decision to make Bertha's home her family home also indicates a desire to continue the family story.

As we find out, Bertha's house is not the only legacy that she has passed on to the subsequent generations. Towards the end of the narrative, Iris suggests that her mother, Christa, is already beginning to show some of the symptoms of the illness that took Bertha's life; she is becoming increasingly disoriented in her own home and has begun to withdraw into herself. This concept of dementia being passed from mother to daughter is rooted in fact; medical research indicates that certain types of dementia, particularly early-onset Alzheimer's Disease, can be inherited (National Institute on Ageing 2011: 2). Although genetic testing cannot accurately predict whether the children of dementia sufferers are likely to develop the disease, the genetic predisposition for the illness can provoke considerable anxiety in adult children of patients (Stone and Jones 2009: 678). Therefore, even members of the family who do not go on to develop the dementia are thus affected by its legacy, and this also features in Hagena's novel: Iris and her father are left to care for Christa and help her to cope with the demands of her daily life, while Inga and Harriet, Bertha's other two daughters, must deal with their grief at losing their mother prematurely and at seeing their sister follow in her footsteps.

The genetic legacy of dementia is also an issue in Gerlof's Alle Zeit. At fifty-nine, Henriette, Klara's daughter, is described from the outset as confused: 'Henriette is uncertain. In everything that she does, she feels this uncertainty' 
(Gerlof 2009: 18). Elisa, Henriette's daughter, observes how simple things such as street signs and public transport cause such anxiety in her 'still so young yet already so confused mother' (19), and she cannot explain it to herself. Through the stories Henriette reveals about her childhood in wartime, about her austere and emotionally distant mother who leaves her alone at night to visit her Russian lover and who later reacts with anger and disgust to the news of her daughter's teenage pregnancy, Elisa supposes that Henriette's anxiety and her inability to open up about the past is a consequence of the inadequate mothering that she received. However, since Henriette has not spoken to her mother in more than a decade, she is not aware that her genetic heritage also includes a propensity for dementia. Ironically, the narrative perspective of the novel means that only the reader is privy to the information about Klara's dementia and thus of the more ominous implications of Henriette's confusion.

Notwithstanding this gap in their knowledge, the women in this family are all too aware of the extent to which their genes might dictate their future health. This is linked to another disease that is most commonly associated with women and one which is also proven to have a genetic basis, namely breast cancer. Henriette knows from the scars that she saw on her mother's body that Klara underwent a double mastectomy in her late twenties as a result of breast cancer. Klara goes to great pains to hide what she sees as her mutilated body from her daughter, and indeed, even at the age of eighty, the physical and emotional scars that this amputation has left are still obvious. More than anything else, Klara is ashamed of her scars, which she interprets as a physical punishment for her infidelity during the war years. However, Klara's brush with breast cancer has also left its mark on subsequent generations; conscious of her increased risk for cancer, Henriette is extremely vigilant about having regular mammograms, and she reminds Elisa to do the same. Elisa is irritated by her mother's advice: 'She often got annoyed that there seemed to be only one theme whenever she tried to talk about Klara. Breast cancer and the dangers it poses for all of the female descendants. As though her grandmother had only consisted of two breasts' (55).

Henriette's pragmatism in the face of illness is also evident in her reaction to the migraines she suffers, and her uncompromising response to this illness emphasizes the physical as well as the mental resemblance between mother and daughter. Once she realizes that her migraines are hormonally induced, Henriette makes the radical but very effective decision to undergo a hysterectomy in order to bring an end to her headaches. Since these migraines have also been passed from Henriette to her daughter, Elisa also gives thought to the consequences of such a stark remedy: 'I should do that as well. Three little holes 
in my belly, out with my womb and maybe never another headache again. Fuck the desire that might go down the drain with it' (32). Both Klara and Henriette have intentionally sacrificed parts of their female bodies to rid themselves of disease, even where this has negatively affected their feelings about their bodies or their libido. Their pragmatic approach to illness in the novel - and, significantly, to illnesses that have a genetic component - serves also to underline that dementia cannot be overcome as simply or as effectively.

Both novels contemplate another type of legacy that is passed from mother to daughter, namely the family history that is communicated on through storytelling. In these multigenerational family narratives, the transmission of family history is fundamental to both the content and the form of the novels. On the one hand, the stories that are told and retold by the female family members emphasize a shared past and a common family identity. On the other, they indicate a sense of inevitability - that daughters cannot help but make the same mistakes as their mothers, and that the family history is also the family destiny. In Hagena's The Taste of Apple Seeds, Iris's cousin Rosmarie falls to her death at the age of sixteen, the same age her great-aunt Anna was when she met her untimely death; in Alle Zeit, three of the five generations of women fall pregnant at a young age and are forced through circumstances to bring up their daughters alone.

In both novels, the need to tell and understand the family story is thus presented in strongly gendered terms, as each of the women in the novels seeks to comprehend the role she plays within the family narrative. In Hagena's The Taste of Apple Seeds, Bertha's death and the hidden stories of her past that emerge in its aftermath cause her granddaughter Iris to look differently on her family history and on her own position as inheritor of Bertha's legacy (Heffernan 2015). In the case of Gerlof's text, Elisa's longing to get to know Klara, the missing chapter of the family story, is motivated by a similar need to understand the past that binds them together. Elisa tries to justify to Henriette her determination to go against her mother's wishes and look for Klara: 'She's my grandmother, Juli's great-grandmother. I've never argued with her, she didn't hurt me or leave me alone. I just want to know what she's like and how she smells. The stories she tells, maybe. You must understand that, mother' (Gerlof 2009: 31-32). Later, Juli is driven by the same motivation; inspired in particular by the birth of her own daughter and by her need to continue the family narrative, she is eager to find the one female relative she has left, the great-grandmother she has never met but whose stories have been passed down through the family. Speaking to her 
newborn daughter, Juli tells Svenja, 'My mother told me stories of all the other mothers and I'll tell them to you' (16-17).

\section{Conclusion: The reader's perspective}

Literary texts such as The Taste of Apple Seeds or Alle Zeit have a powerful part to play in telling the story of those who are living with dementia and in fostering empathy for their situation. Literary fiction allows us to view the world from the eyes of the characters and to imagine what it might feel like to care for a loved one with dementia or to live with the illness ourselves. This empathetic engagement with the personal side of dementia is made all the more compelling when the writers of those literary texts experiment with elements of style, form, and narrative technique in such a way that readers experience for themselves the confusion and disorientation that go hand in hand with dementia. The following section will explore the various ways in which Katharina Hagena and Kathrin Gerlof weave dementia into the fabric of their writing and thereby plunge the reader into the world of the person with the illness or that of their carers.

One aspect of the memory loss typical of dementia that is explored in both novels is the extent to which Klara and Bertha forget details of the present and of recent events but remember events and episodes from the past in vivid detail. This is typical of many people living with dementia, for whom the past is more present than the present itself. The narration of such complex concepts of memory also demands unconventional strategies for representing time, and Hagena's and Gerlof's novels use similar techniques to depict the erosion of the distinction between past and present. Both novels make use of vivid flashbacks to bring the past into the present. In both, the past is told in the present tense, representing the immediacy of events that took place years earlier. Both novels skip between past and present events, often without warning or explanation. Köhler uses the idea of a pendulum swinging between past and present to depict Klara's daily life in Alle Zeit; however, the image of the pendulum implies a regularity and predictability that is not reflected in Klara's demented view of the world (Köhler 2013: 238).

For a reader used to a linear narrative, with a clear distinction between past, present, and future, the repeated jumps between past and present can make the reading of both Hagena's and Gerlof's novels a disorientating experience, but it is precisely this confusion that is most effective in drawing the reader into the world of the person with dementia. Joe Moran points to a similar phenomenon in the way in which John Bayley's Iris: A Memoir of Iris Murdoch is narrated and argues 
that the fragmentariness of the narrative structure is crucial to the way dementia narratives such as Bayley's attempt to represent the muddled chronological perception of the person with dementia: 'The rejection of conventional narrative coherence is part of an overall sense within these texts of the unrepresentability of dementia, the difficulty of positioning it within traditional ways of viewing both identity and aging' (Moran 2001: 258). Indeed, one might contend that the only way to properly communicate the temporal disorientation of dementia to the reader is to compel him/her to experience the events in a similar manner. Hagena's and Gerlof's novels do not attempt to impose an artificial order on the chaotic worldview of their demented subjects; rather, they try to reflect the temporal discontinuity of dementia through a disjointed narrative structure.

Similarly, both novels play with characterization in a way that reflects how people with dementia can confuse people with one another. In the same way that Bertha in The Taste of Apple Seeds confuses her daughters with one another or, later, as her dementia progresses, with her sister, Anna, who died at the age of sixteen, the text plays on the similarities between the female family members and invites the reader to confuse the characters in the novel. The cousins Iris and Rosmarie and their friend Mira love nothing more than to dress up in their mothers' and aunts', grandmothers', and great-aunts' clothes and cycle their old bicycles down the same lanes they used to travel, and the reader cannot fail to notice how their appearance and behaviour replicates that of the women who came before them. Rosmarie's premature death after a fall from the garden house reflects Anna's death, two generations earlier, when she contracted pneumonia after spending the night under a tree in the apple orchard and, given how these two untimely deaths recur and cross paths in the narrative, the reader might be forgiven for failing to differentiate between them. The way in which the characters seem at times to blur together can be bewildering to the reader and this bewilderment gives the reader a small taste of the confusion associated with dementia.

Alle Zeit confounds the reader in a slightly different fashion. Each chapter of the narrative is written from a different perspective, and the impersonal narrative form means that the protagonists are often not named until quite late in the chapter. In effect, this means that the reader must make an effort to interpret the various internal and external clues offered in the text in order to discern which character is the focus of the writing. This endeavour mirrors Klara's experience of dementia, as it is presented in the text; she struggles at times to understand how the people in her life relate to her. She is forced to decipher the world around her in an effort to understand where she is and what is happening. In this 
way, the literary style of the text puts the reader into the position of the person with dementia and forces him/her to imagine the experience of living with this disease. It is only when the reader experiences for himself/herself the confusion and disorientation that are central to this illness that they have an inkling of what it might feel like to live with dementia.

This is perhaps the one point on which the two novels depart and where Gerlof's novel takes the depiction of dementia a step further. Although Hagena's The Taste of Apple Seeds offers a deeply thoughtful picture of the difficulties associated with caring for a loved one with dementia, it is mediated from the point of view of Iris, the youngest member of the Lünschen family, who is two generations removed from her grandmother. It thus tells the story of dementia from the outside and cannot offer the same level of insight into the perspective of a person who is living with the disease and who views the world around them through its lens. Thus, while Hagena's novel can certainly offer some sense of the broader impact of dementia on the family of the sufferer, Iris's intervention in the narrative means that the perspective of the carer is privileged over that of the person with dementia.

Gerlof's Alle Zeit, by contrast, includes the perspective of the person with dementia and thus forces the reader to view the world through the eyes of someone whose experience and perception of the world around her is profoundly shaped by the experience of dementia. The manner in which the reader is plunged into the chaos of Klara's demented worldview encourages him/her to empathize with her vulnerable position and to imagine what it might feel like to live with the illness. The identification with the dementia sufferer that is made possible by the narrative technique and enacted through Gerlof's literary style underlines the role of literary texts in promoting awareness, consideration and, above all, empathy for people who are living with Alzheimer's and other forms of dementia.

\section{Notes}

1. All translations from Kathrin Gerlof's Alle Zeit are my own.

\section{Works cited}

ABC News (2010) 'Alzheimer's daughter: Maria Shriver takes on disease with second Shriver Report', 15 October. http://abcnews.go.com/Health/Alzheimers/ 
maria-shriver-takes-alzheimers-disease-latest-shriver-report/story?id=11815095 \&page=2\#.T7quttxBuSo (accessed 31 August 2017).

Alzheimer's Association (2017) '2017 Alzheimer's disease facts and figures', Alzheimer's \& Dementia 13: 325-373. https://www.alz.org/documents_custom/2017-factsand-figures.pdf (accessed 31 August 2017).

Alzheimer's Disease International (2016) World Alzheimer Report 2016: Improving Healthcare for People Living with Dementia. Coverage, Quality and Costs Now and in the Future. https://www.alz.co.uk/research/WorldAlzheimerReport2016. pdf (accessed 31 August 2017).

Deutsche Alzheimer Gesellschaft e.V. (2016) Das Wichtigste - Informationsblatt 1: Die Häufigkeit von Demenzerkrankungen. http://www.deutsche-alzheimer.de/ fileadmin/alz/pdf/factsheets/FactSheet01_2012.pdf (accessed 31 August 2017).

Eurostat (2015) Population Structure and Ageing, Table 1: Population structure by major age groups, 2004 and 2014 (\% of the total population). http://ec.europa.eu/ eurostat/statistics-explained/index.php/File:Population_age_structure_by_ major_age_groups,_2004_and_2014_(\%25_of_the_total_population)_YB15.png (accessed 31 August 2017).

Gerlof, Kathrin (2009) Alle Zeit (Berlin: Aufbau).

Hagena, Katharina (2008) Der Geschmack von Apfelkernen (Köln: Kiepenheuer \& Witsch).

Hagena, Katharina (2013) The Taste of Apple Seeds, trans. Jamie Bulloch (London: Atlantic).

Heffernan, Valerie (2015) 'Matrilineal narrative and the feminist family romance', in German Women's Writing in the Twenty-First Century, ed. Hester Baer and Alexandra Merley Hill (Rochester, NY: Camden House), 37-53.

Keen, Suzanne (2007) Empathy and the Novel (Oxford: Oxford University Press).

Köhler, Astrid (2013) 'Große Form - kleine Form. Gegen den Strich der Familiensaga', in Poetiken der Gegenwart. Deutschsprachige Romane nach 2000, ed. Silke Horstkotte and Leonhard Herrmann (Berlin and New York: de Gruyter), 229-243.

Krüger-Fürhoff, Irmela Marei (2015) 'Narrating the limits of narration: Alzheimer's disease in contemporary literary texts', in Popularizing Dementia: Public Expressions and Representations of Forgetfulness, ed. Aagje Swinnen and Mark Schweda (Bielefeld: Transcript), 89-108.

Matthews-Schlinzig, Marie Isabel (2015) 'Introduction', Oxford German Studies 44, special number: 'Writing in extremis': $1-2$.

Moran, Joe (2001) 'Aging and identity in dementia narratives', Cultural Values 5: 245-260.

National Institute on Ageing (2011) 'Alzheimer's disease genetics fact sheet', National Institutes of Health Publication no. 11-6424. https://www.nia.nih.gov/health/ alzheimers-disease-genetics-fact-sheet (accessed 31 August 2017).

Shafi, Monika (2012) Housebound: Selfhood and Domestic Space in Contemporary 
German Fiction, Studies in German Literature Linguistics and Culture Vol. 121 (Rochester, NY: Camden House).

Shriver, Maria, and the Alzheimer's Association (2010) Alzheimer's in America: The Shriver Report on Women and Alzheimer's (New York: Simon \& Schuster).

Stone, Anne Margaret, and Christina L. Jones (2009) 'Sources of uncertainty: Experiences of Alzheimer's disease', Issues in Mental Health Nursing 30: 677-686.

Swinnen, Aagje, and Mark Schweda (eds) (2015) Popularizing Dementia: Public Expressions and Representations of Forgetfulness. Ageing Studies Vol. VI (Bielefeld: Transcript).

Taberner, Stuart (2013) Aging and Old-Age Style in Günter Grass, Ruth Klüger, Christa Wolf, and Martin Walser: The Mannerism of a Late Period (Rochester, NY: Boydell \& Brewer).

Vedder, Ulrike (2012) 'Erzählen vom Zerfall. Demenz und Alzheimer in der Gegenwartsliteratur', Zeitschrift für Germanistik 22: 274-289.

World Health Organization (2017) Dementia: Fact Sheet No. 362. http://www.who. int/mediacentre/factsheets/fs362/en/ (accessed 31 August 2017).

World Health Organization and Alzheimer's Disease International (2012) Dementia: A Public Health Priority (Geneva: World Health Organization). http://apps. who.int/iris/bitstream/10665/75263/1/9789241564458_eng.pdf?ua=1 (accessed 31 August 2017).

Zimmermann, Martina (2010) 'Deliver us from evil: Carer burden in Alzheimer's disease', Medical Humanities 36: 101-107.

Valerie Heffernan is a Senior Lecturer in German at the Maynooth University School of Modern Languages, Literatures and Cultures. She is the author of Provocation from the Periphery: Robert Walser Re-examined (2007) and is currently working on her second monograph, Contemporary Women's Writing in German: The Feminist Family Romance, which is based in part on a research project entitled 'The Cultural Transmission of Motherhood in Europe: A Case Study', for which she was awarded a prestigious Irish Research Council Starter Research Project Grant in 2014. She is co-editor of Transitions. Emerging Women Writers in Germanlanguage Literature (2013) and co-editor of Schweiz schreiben: Zu Konstruktion und Dekonstruktion des Mythos Schweiz in der Gegenwartsliteratur (2010).

Email: Valerie.Heffernan@mu.ie 